\title{
Салехардская научно-исследовательская ветеринарная оленеводческая станция в 1940-1945 гг.
}

\section{Введение}

В современной науке с каждым годом всё более и более возрастает интерес к проблемам истории, настоящего и будущего Арктических территорий [3], в том числе и Арктической зоны Российской Федерации (далее АЗРФ) [5]. Российская Арктика - это в первую очередь территория, значительно отличающаяся от других регионов нашей страны. Современными учеными поднимается широкий сектор вопросов, посвящённых развитию регионов, входящих в территорию АЗРФ [8]. Изучая современность и разрабатывая новые концептуальные подходы, исследователи всё чаще обращаются к советскому историческому опыту развития данных регионов [4]. В состав АЗРФ входит 8 субъектов Российской Федерации, в том числе такой уникальный регион, как Яммало-Ненецкий автономный округ, в котором на данный момент выпасается самое крупное в мире и в России стадо северных оленей [7]. Оленеводческая отрасль Ямало-Ненецкого автономного округа является важной частью современной экономики региона [1], однако развитие отрасли было бы невозможным без научного сопровождения отрасли специальными ветеринарными учреждениями [2], которые занимались изучением и внедрением передовых ветеринарных технологий в хозяйственную отрасль.

В Ямало-Ненецком округе в XX в. таким учреждением стала Салехардская ветеринарная оленеводческая станция, которая была образована в 1925 г. в городе Салехард (на тот момент селе Обдорском) изначально как Обдорский ветеринарно-бактериологический институт, который в 1931 г. был преобразован в Салехардскую научно-исследовательскую ветеринарную опытную станцию (далее по тексту НИВОС). Назначение станции заключалось в изучении заразных болезней северных оленей, разработке мер борьбы с ними, популяризации полученных знаний и непосредственном осуществлении в оленеводческих хозяйствах мероприятий, направленных на оздоровление поголовья оленей (ГА ЯНАО. Ф. 95. Оп. 4. Д. 20. Л. 32. (Отчет о научно исследовательской работе станции за 1940 г.)) ${ }^{1}$. История Салехардской НИВОС достаточно обширна, ранее учеными проводились исследования работы станции в контексте научной деятельности, реализуемой на территории округа в XX в.

Цель настоящей статьи: выявить и показать особенности работы Салехардской НИВОС в один из самых сложных периодов нашей страны - годы Великой Отечественной войны. В частности, осветить вопросы материального обеспечения станции, обеспеченности кадрами и определить, как менялся вектор научных направлений учреждения. Хронологические рамки статьи охватывают время накануне и годы Великой Отечественной войны.

В качестве исторических источников автором избраны архивные материалы, сохранившиеся в архивном фонде № 95 "Салехардская научно-исследовательская ветеринарная станция (НИВОС) по изучению болезней северных оленей Министерства сельского хозяйства СССР", в котором сохранились

1 ГА ЯНАО - Государственный архив Ямало-Ненецкого автономного округа

(C) Рябкова О. В., 2021

РЯБКОВА Ольга Викторовна, младший научный сотрудник научно-исследовательского отдела, сектора истории и археологии Научного центра изучения Арктики (2. Салехард). E-mail: ryabkova.olga2016@yandex.ru 
документы, относящиеся непосредственно к деятельности организации за период с 1925 по 1957 гг.

Научная деятельность Салехардской НИВОС и ее роль в экономике региона, отражена в работах исследователей, которые занимаются изучением Ямало-Ненецкого региона. Так, работой, которая освещает вопрос истории создания и становления в регионе первого научного учреждения за 75 лет, является статья А.А. Южакова [6], который провёл ретроспективный анализ научных проблем в областях ветеринарии, зоотехники, охоты, промысла [6]. Деттер Г.Ф. [2] дал обзор исторических событий, связанных со становлением и развитием науки в Ямало-Ненецком автономном округе, в том числе и Салехардской НИВОС. Автором указываются основные направления работы станции в течении первых 30 лет существования как самостоятельного учреждения. Данные научные работы имеют важное историческое значение, так как впервые за всё время функционирования Салехардской НИВОС была освещена её научная деятельность и роль в системе управления оленеводческой отрасли округа.

\section{Салехардская научно-исследовательская ветеринарная опытная станция: история основания и работа в 1941 г.}

Как отмечалось выше, основными задачами учреждения являлось обслуживание оленеводческих хозяйств, научное изучение болезней северных оленей и выработка мер и средств борьбы с ними. Подчинялась станция Народному комиссариату земледелия СССР (далее по тексту НКЗ СССР). Научный тематический план организации до войны отправлялся на утверждение в Главное управление НКЗ СССР и во Всесоюзный институт экспериментальной ветеринарии (далее ВИЭВ) (ГА ЯНАО. Ф. 95. ОП. 2. Д. 30 Л. 2. (Научно-технический отчет Салехардской НИВОС за 1940 г.)). Финансирование станции в 1940 и 1941 гг. производилось за счет государственного и местного бюджета. За государственный счет станция работала по направлениям, которые имели общегосударственное значение. Во-первых, это изучение заразных болезней и разработка мер по борьбе с ними. Во-вторых, выполнение мероприятий по оздоровлению поголовья одомашненных сельскохозяйственных животных при заразных и незаразных болезнях. За счет средств местного бюджета станция проводила лабораторно-диагностическую работу по установлению диагноза на заразность животных и исследованию кожевенного и мехового сырья на сибирскую язву (ГА ЯНАО Ф. 95. Оп. 4. Д. 20. Л. 32. (Научно-технический план и отчет о деятельности НИВОС в 1940-1941 гг.)).

На начало 1941 г. учреждение состояло из четырех научно-исследовательских отделов. Первый отдел - это "эпизоотический", сотрудники которого занимались изучением распространения инфекционной болезни среди сельскохозяйственных животных округа, в основном северных оленей. В этом отделе работало четыре сотрудника: 2 старших научных сотрудника, лаборант и препаратор-санитар. Второй отдел станции - "экспериментальной диагностики", в нём работало два человека: научный сотрудник и лаборант (веттехник). Третий отдел - "протозоологии" - занимался изучением болезней животных, вызываемых простейшими организмами. В нем работало два человека: старший научный сотрудник и уборщица-препаратор. Четвертый отдел - "гельминтологии". В данном отделе работало два человека: научный сотрудник и лаборант. Кроме научно-исследовательских отделов в учреждении имелся административно-управленческий аппарат, который включал в себя директора и помощника директора по административно-хозяйственной части, бухгалтера и секретаря. На станции имелись подсобные рабочие, которые относились к хозяйственному отделу: дворовый рабочий и пастухи (3 человека) (ГА ЯНАО Ф. 95. ОП. 1.Д.18. Л. 6. (Годовой бухгалтерский отчет за 1941 г.).

В Салехардской НИВОС не было ни одного остепенённого сотрудника, однако квалификация и опыт работы научных сотрудников были достаточно высокими. Пять человек, в том числе директор станции, имели высшее образование по специальности ветврач, все работали в ветеринарии более 9 лет.

Директор станции Антон Гаврилович Ревнивых в 1922 г. окончил Тобольский ветеринарный техникум, затем в 1931 г. - Омский ветеринарный институт, к 1941 г. стаж работы в ветеринарии составил 14 лет. Научный со- 
трудник Мария Владимировна Полянская окончила в 1931 г. Омский ветеринарный институт, общий стаж работы по специальности - 9 лет. Старший научный сотрудник Алексей Алексеевич Ключарев окончил в 1918 г. Казанский ветеринарный институт и по спещиальности работал уже 24 года. Старший научный сотрудник Александр Клементьевич Краснобаев в 1931 г. окончил Омский ветеринарный институт, стаж работы - 9 лет. Научный сотрудник Зинаида Александровна Балабырдина окончила Омский государственный институт в 1931 г., стаж работы по специальности - 9 лет (ГА ЯНАО Ф. 95. Оп. 1.Д.18. Л. 45. (Годовой бухгалтерский отчет за 1941 г.)).

Образование сотрудников административно-хозяйственного аппарата станщии было значительно ниже. Заведующий хозяйством учреждения Ефимов Н.Ф. имел 5 классов, бухгалтер Гольберг Б.И. -8 классов, секретарь Сергеева Т.Д. -7 классов.

Подсобные работники имели только школьное образование: лаборант отдела гельминтов Седельникова О. - 8 классов, лаборант протозоологического отдела Федотова П. И. - 7 классов, санитар-препаратор Аксарина Е. Н. - малограмотная, уборщицы - Пьянкова П. Е. и Ашихмина О. Т. - малограмотные, дворовый рабочий - 3 класса образования, пастухи - неграмотные (ГА ЯНАО Ф. 95. ОП. 1.Д.20. Л. 5. (Штатное расписание и смета расходов Салехардской НИВОС)).

Согласно документу "Выписка из сметы расходов Салехардской НИВОС за 1941 г.", годовой бюджет станции в 1941 г. составил 210000 рублей, из них 163000 рублей было выделено на зарплаты штатных сотрудников (административно-управленческий аппарат и научно-исследовательский персонал), на зарплату временным и сезонным рабочим было потрачено 1800 рублей (ГА ЯНАО Ф. 95. Оп. 1.Д.18. Л. 3. Выписка из сметы расходов Салехардской НИВОС за 1941 г.). Самой высокооплачиваемой научной должностью станций являлась ставка "старшего научного сотрудника", оклад которого составлял - 675 рублей, оклад "научного сотрудника" - 500 рублей, "оклад лаборанта" - 225-240 рублей, "санитара и уборщицы" - 200 рублей. Оклады административно-управленческого аппарата различались размерами: так ставка "директора" составляла - 950 рублей, "бухгалтера" - 600 рублей, ставка "помощника директора" - 450 рублей, ставка "секретаря" - 275 рублей. К окладам постоянным работникам полагались надбавки по выслуге лет. Временные и сезонные рабочие имели следующие оклады: "дворовый рабочий" 225 рублей, "старший пастух" - 400 рублей, "пастух" - 300 рублей, "младший пастух" - 250 рублей (ГА ЯНАО Ф. 95. Оп. 1.Д.18. Л. 2. Выписка из сметы расходов Салехардской НИВОС за 1941 г.).

В начале 1941 г. станция работала в штатном режиме, работники станции готовились к полевому сезону, а в феврале 1941 г. состоялось важное для организации заседание, на котором рассматривался серьезный вопрос "Кто будет представлять станцию на предстоящей Всесоюзной сельскохозяйственной выставке 1941 г.?". На заседании рассматривались характеристики сотрудников НИВОС: научных сотрудников, кандидатов и их научные заслуги. Согласно протоколу заседания, были утверждены заявления: Краснобаева А. К., Ключарева А. А., Полянской М. В., Ревнивых А. Г. А также было решено представить на выставке результаты работы межрайоной ветлаборатории и самой НИВОС (ГА ЯНАО Ф. 95. Оп. 1. Д. 19 Л. 17. (Протокол заседания № 1 за 1941 г.)).

Согласно плану, в 1941 г. на станции должны были быть проведены следующие работы по 6 направлениям:

1) Анализ заболеваемости и смертности сельскохозяйственных животных и изучение эффрективности противоэпизоотических мероприятий при копытной болезни, пироплазмозе, сибирской язве, глистной инвазии северных оленей.

2) Проверка сохраняемости в почвах некроза и некробацилл в патологических материалах.

3) Испытание лечебных свойств противосибироязвенной сыворотки.

4) Испытание лечебных свойств вакцин при пироплазмозе северных оленей.

5) Изучение микробов, выделенных от оленей с копытной болезнью. 
6) Изучение нематодиреллёза телят северных оленей. (ГА ЯНАО Ф. 95. Оп. 1. Д. 19 Л. 16. (Протокол заседания № 1 за 1941 г.))

Кроме работ, по плану намеченных на 1941 г., работники на станции участвовали в изучении массового падежа оленей от сибирской язвы в Ямальском и Надымском районах. Для определения и ликвидации появившегося заболевания в колхозное стадо отправился А. Г. Ревнивых (ГА ЯНАО Ф. 95. Оп. 1. Д. 19 Л. 1. (Протокол заседания № 1 за 1941 г.)).

После начала войны работа станции не была прекращена, но планы на будущее подверглись корректировке. 30 сентября 1941 г. на адрес станции было направлено письмо от начальника главного управления научно-исследовательских учреждений НКЗ СССР, в котором директору Салехардской НИВОС поручалось немедленно приступить к составлению тематического плана на 1942 г.

При этом разработка планов должна была проводиться в соответствии с условиями военного времени, что значило изменение вектора работы. От учреждения требовалось начать работу над темами, которые возможно было внедрить за короткий промежуток времени. Сохранению подлежали только те многолетние научные темы, которые затрагивали вопросы селекции, племенного дела, севооборота и другие ценные многолетние агротехнические опыты (ГА ЯНАО Ф. 95. ОП. 4. Д. 20. Л. 31. (Переписка с начальником главного управления научно-исследовательских учреждений НКЗ CCCP)). В связи с перестройкой работы научных учреждений на военный лад Салехардская НИВОС должна были пересмотреть научные тематические планы и методы исследований. При этом учитывать, что государственное фонансирование будет сокращенно на 50\% (ГА ЯНАО Ф. 95. Оп. 4. Д. 20. Л. 31. (Переписка с начальником главного управления научно-исследовательских учреждений НКЗ СССР)). Кроме того, в войну были отменены отпуска, в том числе и для научных сотрудников, а также сокращено количество проводимых опытов. По этой причине перед научными организациями появилась новая задача: начать изготовление витаминных концентратов (ГА ЯНАО Ф. 95. Оп. 4. Д. 20. Л. 32. (Переписка с начальником главного управления научно-исследовательских учреждений НКЗ СССР)). Новой задачей для учреждений науки стала массовая подготовка кадров для производства, так как в связи с войной на фронт ушло много квалифицированных специалистов. В условиях войны от опытных научных учреждений требовалось начать внедрение полученных результатов в производство и начать повседневную производственную помощь колхозам. Перед учреждениями ставилась задача: начать пропаганду научных результатов среди населения.

\section{Салехардская НИВОС в 1942-1945 гг.}

С учетом присланных в сентябре 1941 г. рекомендаций от начальника главного управления научно-исследовательских учреждений НКЗ СССР в марте 1942 г. состоялось совещание НИВОС, на котором рассматривался тематический научный план на 1942 г.

Согласно плану, станция должна была продолжить работу по трём научным проблемам. Во-первых, провести анализ заболеваемости и смертности $\mathrm{c} / \mathrm{x}$ животных и изучение эфорективности противоэпизоотических мероприятий с непосредственным внедрением научными сотрудниками станции в колхозные оленеводческие хозяйства комплекса оздоровительных мероприятий. Для работы были выбраны колхозы "Красная Москва" и "Имени Ворошилова" в Тазовском районе. Ответственным исполнителем назначен А.К. Краснобаев, в колхозах "Едай Ил" и "Передовик" Ямальского района - исполнитель Ревнивых, в колхозах "Красная звезда", "Красный октябрь", "20-лет Октября" Приуральского района - исполнители А. А. Ключарев и М. В. Полянская. Вторым направлением стало исследование вопроса "Обитает ли палочка некроза в почвах тундры с учетом РН?". Ответственным исполнителем назначен А. К. Краснобаев. Третье направление - это продолжение ведения многолетней работы по изучению нематодореллеза среди телят северных оленей, вопросом занималась М. В. Полянская (ГА ЯНАО Ф. 95. Оп. 4. Д. 20. Л. 31. (Отчет Салехардской НИВОС за 1942 г.)). 
Утвержденный на заседании план работы станции был отправлен на проверку во Всесоюзный институт экспериментальной ветеринарии, из ВИЭВ пришел ответ, что замечаний к плану нет и он принят. Бюджет Салехардской НИВОС на 1942 г. составил 197400 рублей, в том числе на зарплату сотрудникам выделялось 140200 рублей (ГА ЯНАО Ф. 95. Оп. 4. Д. 20. Л. 47. (Отчет Салехардской НИВОС за 1942 г.)). При этом количество работников станции уменьшилось на одного человека - Едимов Николай Федорович отправился на фронт, количество научных сотрудников осталось прежним. Уход на фрронт из региона квалифицированных специалистов способствовал повышению нагрузки на тружеников тыла, не была исключением и Салехардская НИВОС. В 1942 г. директору станции Ревнивых, который уже совмещал научную и административную работу, пришлось взять на себя дополнительную нагрузку -сверх плана с 1 февраля по 20 февраля 1942 г. он исполнял обязанности главного ветеринарного врача Ямало-Ненецкого национального округа (ГА ЯНАО Ф. 95. Оп. 4. Д. 20. Л. 47. (Отчет Салехардской НИВОС за 1942 г.)).

Выполняя обязанности главного ветеринарного врача, А. Г. Ревнивых провел проверку производственной деятельности Нумгинского, Пуровского, Мужевского, оленеводческих совхозов. На основе данной работы им был разработан развернутый комплексный план практического осуществления противосибироязвенных мероприятий в оленеводческих хозяйствах Ямало-Ненецкого округа на 1942 г. (ГА ЯНАО Ф. 95. Оп. 4. Д. 20. Л. 140 (Отчет Салехардской НИВОС за 1942 г.)).

Война коренным образом изменила работу многих организаций страны, в том числе и Салехардской НИВОС. В 1942 г. пришлось взять на себя руководство ветеринарной группой Ямальской оленеводческой зональной станции Института Полярного земледелия и животноводства НКЗ СССР, так как институт в сложившихся условиях не мог оказывать систематическое руководство работы Ямальской оленеводческой станции (ГА ЯНАО Ф. 95. Оп. 4. Д. 20. Л. 54. (Отчет Салехардской НИВОС за 1942 г.)). По этой причине Народный комиссариат земледелия СССР возложил данные функции на Салехардскую НИВОС (ГА ЯНАО Ф. 95. Оп. 4. Д. 20. Л. 54. (Отчет Салехардской НИВОС за 1942 г.)). Уже в марте 1943 г. в Салехард был направлен научный сотрудник Ямальской оленеводческой станции И.И. Орлов для получения методического руководства по теме "Анализ заболеваемости и смертности северных оленей и изучение эффрективности проводимых противоэпизоотических мероприятий" и "Внедрение в колхозное и совхозное оленеводство комплекса оздоровительных мероприятий против так называемой копытной болезни оленей". И.И. Орлов разрабатывал данные темы и апробировал их в стаде № 6 Ныденского совхоза (ГА ЯНАО Ф. 95. Оп. 4. Д. 20. Л. 55. Переписка с Ямальской оленеводческой станцией).

При составлении и реализации работ станции в годы войны учитывались замечания Главного управления научно-исследовательских учреждений НКЗ СССР от 30 сентября 1941 г. за № 340, особенно пункт по внедрению достижений науки в производство и оказание повседневной практической помощи колхозам и совхозам, перерастающей в организационную.

Для определения наиболее перспективных для округа научно-исследовательских направлений станции уже в 1943 г. при рассмотрении планов на будущее на заседаниях станции стали присутствовать представители окружных организаций. На заседании станции от 11 января 1943 г., посвященном составлению научно-тематического плана, присутствовали представитель сельскохозяйственного отдела ОК ВКП(б), ветврач и старший зоотехник ОКРЗО, агроном округа, представитель Института полярного земледелия Ямальской НИЗОС, Ямальской сельскохозяйственной опытной станции, Салехардской метеостанции, Салехардского совхоза, зоотехники Салехардского зооветеринарного технического участка (ГА ЯНАО Ф. 95. Оп. 4. Д. 22. Л. 1. Протокол заседания Салехардской НИВОС 11 января 1943 г.).

На заседаниях подробно обсуждались итоги научной работы станции за 1942 г. и рассматривались планы на будущее. Итогом заседания стало создание Окружной комиссии, которая должна была предложить проект решения Исполкома ЯНАО ОК по вопросу оценки итогов работы станции и утверждения планов работы на 1943 г. (ГА ЯНАО Ф. 95. Оп. 4. Д. 22. Л. 8. Прото- 
кол комиссии о итогах работы Салехардской НИВОС). Согласно решению комиссии, работа станции 1942 г. была признана успешной, так как "в течение 1942 г. специалисты, выполняя научно-исследовательскую работу в оленстадах, проделали большую работу в области оказания практической ветеринарной помощи оленеводческому хозяйству колхозов" (ГА ЯНАО Ф. 95. ОП. 4. Д. 22. Л. 10. Протокол комиссии о итогах работы Салехардской НИВОС).

Итоговый научно-тематический план в 1943 г. был составлен с учётом потребностей региона в научных исследованиях и возможностях Салехардской НИВОС. В фреврале 1943 г. Главное управление Наркомата земледелия CCCP утвердило тематический план с учетом количества научных кадров станции. Так как на станции работало 4 специалиста с высшим образованием, темы тоже было четыре (ГА ЯНАО Ф. 95. Оп4. Д. 22. Л 102. Отчет о работе Салехардской НИВОС за 1943 г.). Первой темой в научном плане стояла работа по испытанию сибироязвенной вакцины "СТИ" на северных оленях, выполнение исследования возлагалось на директора станции А.Г. Ревнивых (ГА ЯНАО Ф. 95. ОП 4. Д. 22. Л. 102. Отчет о работе Салехардской НИВОС за 1943 г.). Вторая утвержденная тема, являясь продолжением ранее начатых работ, звучала как "Выявление обитания палочки некроза в почвах тундры", исполнитель А. К. Краснобаев. Третья научная тема, которую разрабатывали сотрудники станции в 1943 г. - "Опыты оздоровления оленей от оводовой инвазии", исполнитель А. А. Ключарев. Четвертую научную тему вела М. В. Полянская - "Изучение мониэзиоза северных оленей" (ГА ЯНАО Ф. 95. Оп4. Д. 22. Л 102. Отчет о работе Салехардской НИВОС на 1943 .). Кроме научных работ станция продолжала выполнять и диагностические работы сельскохозяйственных животных колхозов округа (ГА ЯНАО Ф. 95. Оп4. Д. 22. Л 112 Отчет о работе Салехардской НИВОС за 1943 г.).

Война повлияла на работу станции, к 1943 г. научные работы стали во многом прикладными и были направлены на потребности развития оленеводства региона. В 1943 г. Салехардская НИВОС стала испытывать кадровый голод, что характерно для многих отраслей региона данного периода. В 1943 г. в Салехардской НИВОС на станции остался работать один лаборант из положенных двух, кроме того, вакантной являлась должность секретаря (ГА ЯНАО Ф. 95. ОП4. Д. 22. Л. 116. Отчет о работе Салехардской НИВОС за 1943 г.).

В годы войны сотрудники станции, как и многие труженики тыла нашего региона, помогали стране и фронту. Формы такой помощи были различными. Так, например, в 1943 г. научные сотрудники станщии помимо своей основной работы заготавливали корма для сельскохозяйственных животных станции, обеспечивали станцию дровами (заготовка и подвоз), занимались сбором стройматериала по берегам рек, а также помогали другим организациям заготавливать дрова - для электростанции заготовлено 22 кубометра дров (ГА ЯНАО Ф. 95. Оп4. Д. 22. Л. 45. Отчет о работе Салехардской НИВОС за 1943 г.). Кроме того, в 1943 г. на станции было организовано подсобное хозяйство в виде коллективного огорода площадью 3450 кв. метров, с которого сняли урожай - 1680 кг. картофеля, а также распахана целина для посева турнепса и картофеля для животных станции (ГА ЯНАО Ф. 95.0 Оп4. Д. 22. Л. 45. Отчет о работе Салехардской НИВОС за 1943 г.].

В 1944 г. работники станции за хорошую работу в своей области были отмечены значком "Отличник социалистического сельского хозяйства" от Народного комиссариата Земледелия: А.Г. Ревнивых, А.А. Ключарев (ГА ЯНАО Ф. 95. Оп4. Д. 23. Л. 86. Приказ о награждении научных сотрудников знаком отличник соцсоревнования Народного комиссариат земледелия), А.А. Краснобаев, З.А. Балабырдина, И.А. Терентьев, В.Г. Сметанин (ГА ЯНАО Ф. 95. Оп4. Д. 23. Л. 86. Приказ о награждении научных сотрудников знаком отличник соцсоревнования Народного комиссариат земледелия). В 1944 г. на станции продолжили научно-исследовательские работы 1943 г. (ГА ЯНАО Ф. 95. ОП4. Д. 23. Л. 1. Отчет о работе Салехардской НИВОС в 1944 гг.). Кроме того, достаточно успешно работал диагностический отдел Салехардской НИВОС: своевременно выполнял диагностику поступающих патоматериалов, что способствовало предупреждению распространения в колхозных стадах заразных заболеваний среди оленей (ГА 


\section{ЯНАО Ф. 95. Оп4. Д. 23. Л. 29. Отчет о работе Салехардской НИВОС в 1944 г.).}

Несмотря на то что война шла далеко и Ямало-Ненецкий округ являлся регионом глубокого тыла, выполнение намеченных планов часто проводилось в достаточно сложных условиях. К 1945 гг. материальная база Салехардской НИВОС пришла в упадок. Ввиду кадрового голода станция испытывала трудности с заготовкой кормов для опытных животных станции, в результате опыты пришлось проводить на меньшем количестве животных, чем требовала методология. Выполнение лабораторных опытов вызывало трудности ввиду отсутствия необходимого количества лабораторного оборудования (стекла, посуды, примусов, спиртовок и пр.) (ГА ЯНАО Ф. 95. Оп4. Д. 23. Л. 29. Отчет о работе Салехардской НИВОС за 1945 г.). За годы войны без достаточного обеспечения экспедиционное оборудование станции (палатки и спецодежда) пришло в негодность, научные сотрудники были вынуждены работать в тундре в плохих условиях. На Салехардской НИВОС отсутствовал в достаточном количестве стройматериал для ремонта хозяйственных и жилых построек (ГА ЯНАО Ф. 95. Оп 4. Д. 23. Л. 110. Отчет о работе Салехардской НИВОС за 1945 г.). На станции практически полностью отсутствовала писчая и копировальная бумага, печатная машинка. Несмотря на все трудности и нехватку рабочих рук (отсутствовали 4 штатные единицы), в 1944-1945 гг. станция выполнила плановую научно-исследовательскую работу в полном соответствии с рабочими программами и указаниями ВИЭВ (ГА ЯННА Ф. 95. Оп4. Д. 23. Л. 130. Отчет о работе Салехардской НИВОС за 1945 г.).

\section{Заключение}

Анализ исторических источников, отложившихся в Государственном архиве Ямало-Ненецкого автономного округа архивного фонда № 95 "Салехардская научно-исследовательская ветеринарная станция (НИВОС) по изучению болезней северных оленей Министерства сельского хозяйства СССР", позволил выявить следующую информащию.

Ежегодно в начале календарного года на станции проводились заседания, на которых рассматривались итоги работы за прошлый год и определялся сектор работ по научно-исследовательским направлениям на текущий. Затем утвержденный план отправлялся на согласование в Главное управление НКЗ СССР и во Всесоюзный институт экспериментальной ветеринарии. В годы войны на заседаниях, посвященных итогам работы и планам на будущее, участвовали представители профильных окружных структур, заинтересованные в ветеринарной научно-исследовательской и экспериментальной деятельности.

В годы войны научные работы стали носить более прикладной характер, так приоритетными стали вопросы внедрения результатов научных исследований в производственные предприятия региона. Установлено, что Салехардская НИВОС получала фринансирование из общегосударственного и местного бюджетов, с началом войны фринансирование было урезано.

В 1941-1945 гг. на станции работало 4 научных сотрудника, не имеющих ученых степеней, но имеющих высшее ветеринарное образование и опыт работы более 10 лет. Кроме того, директор станции А. Г. Ревнивых совмещал административную работу с научно-исследовательской и опытно-экспериментальной деятельностью. В 1941 г. А. Г. Ревнивых отправился в командировку в колхозные стада, охваченные сибирской язвой. В годы войны станция испытывала нехватку подсобного персонала, не хватало лаборантов.

Материальное обеспечение станции в 1941-1945 гг. значительно ухудшилось, отсутствовало необходимое для лабораторной работы оборудование, экспедиционное снаряжение пришло в негодность, на станции практически отсутствовала писчая и копировальная бумага. Несмотря на все трудности, с которыми сталкивались сотрудники станции, в течение всей войны работа станции не прекращалась и находилась на удовлетворительном уровне. 


\section{Литература}

1. Андронов С.В. Продовольственная безопасность коренных народов Арктической зоны Западной Сибири в условиях глобализации и изменения климата / Андронов С.В., Богданова Е.Н., Вороненко А.Г., Гриценко В.Н., Деттер Г.Ф., Кобелькова И.В., Кочкин Р.А., Лобанов А.А., Лобанова Л.П., Попов А.Й., Федоров Р.Ю., Филант К.Г., Филант П.Н., Южаков А.А. /Северный (Арктический) федеральный университет имени М.В. Ломоносова. Архангельск: КИРА, 2020. 373 с.

2. Деттер Г.Ф. Краткая история научно-технологического развития Ямало-Ненецкого автономного округа, итоги / Деттер Г.Ф. // Инновации. 2019. № 1 (243). С. 8590.

3. Замятина Н.Ю. Арктическая урбанизация: феномен и сравнительный анализ / Замятина Н.Ю., Гончаров Р.В. // Вестник Московского университета. Серия 5: География. 2020. № 4. С. $69-82$.

4. Пилясов А.Н., Замятина Н.Ю. Суперорганизации в управлении Арктикой: исторический опыт и современная интерпретация // Государственные и общественные организации в управлении Арктикой: прошлое, настоящее, будущее / Полярные чтения на ледоколе "Красин" - 2019. М.: Издательство "Паулсен", 2020. С. 160-173.

5. Цыкалов А. Г. Основные принципы стратегии социально-экономического развития северных и арктических регионов Красноярского края (края) / Цыкалов А. Г., Гончаров Р. В., Копцева Н. П., Пилясов А. Н., Потураева А. В., Замятина Н. Ю. // Вестник Сибирского федерального университета. Гуманитарные и социальные науки. 2020. T. 13. № 5. C. $800-817$.

6. Южаков А.А. История и основные итоги работы Ямальской СХOC // Труды Всероссийского научно-исследовательского института ветеринарной әнтомологии и арахнологии. Тюмень, 2006. С. 232-240.

7. Южаков А.А. Трансформация оленеводства Арктики в условиях рыночной экономики (на примере Ямала) / Южаков А.А., Деттер Г.Ф. //Арктика: әкология и экономика. 2020. № 4 (40). С. 139-150.

8. Arctic entrepreneurship development factors /Pilyasov A.N. // Geography, Environment, Sustainability. 2020. T. 13. № 1. C. 46-56.

\section{Транслитерация по ГОСТ 7.79-2000 Система Б}

1. Andronov S.V. Prodovol'stvennaya bezopasnost' korennykh narodov Arkticheskoj zony Zapadnoj Sibiri v usloviyakh globalizatsii i izmeneniya klimata / Andronov S.V., Bogdanova E.N., Voronenko A.G., Gritsenko V.N., Detter G.F., Kobel'kova I.V., Kochkin R.A., Lobanov A.A., Lobanova L.P., Popov A.I., Fedorov R.YU., Filant K.G., Filant P.N., YUzhakov A.A. /Severnyj (Arkticheskij) federal'nyj universitet imeni M.V. Lomonosova. Arkhangel'sk: KIRA, 2020.373 s.

2. Detter G.F. Kratkaya istoriya nauchno-tekhnologicheskogo razvitiya YAmalo-Nenetskogo avtonomnogo okruga, itogi / Detter G.F. // Innovatsii. 2019. № 1 (243). S. 85-90.

3. Zamyatina N.YU. Arkticheskaya urbanizatsiya: fenomen i sravnitel'nyj analiz / Zamyatina N.YU., Goncharov R.V. // Vestnik Moskovskogo universiteta. Seriya 5: Geografiya. 2020. № 4. S. 69-82.

4. Pilyasov A.N., Zamyatina N.YU. Superorganizatsii v upravlenii Arktikoj: istoricheskij opyt i sovremennaya interpretatsiya // Gosudarstvennye i obshhestvennye organizatsii v upravlenii Arktikoil: proshloe, nastoyashhee, budushhee / Polyarnye chteniya na ledokole "Krasin" - 2019. M.: Izdatel'stvo "Paulsen", 2020. S. 160-173.

5. TSykalov A. G. Osnovnye printsipy strategii sotsial'no-ehkonomicheskogo razvitiya severnykh i arkticheskikh regionov Krasnoyarskogo kraya (kraya) / TSykalov A. G., Goncharov R. V., Koptseva N. P., Pilyasov A. N., Poturaeva A. V., Zamyatina N. YU. II Vestnik Sibirskogo federal'nogo universiteta. Gumanitarnye i sotsial'nye nauki. 2020. T. 13. № 5. S. 800-817.

6. YUzhakov A.A. Istoriya i osnovnye itogi raboty YAmal'skoj SKHOS // Trudy Vserossijskogo nauchno-issledovatel'skogo instituta veterinarnoj ehntomologii i arakhnologii. Tyumen', 2006. S. 232-240.

7. YUzhakov A.A. Transformatsiya olenevodstva Arktiki v usloviyakh rynochnoj ehkonomiki (na primere YAmala) / YUzhakov A.A., Detter G.F. //Arktika: ehkologiya i ehkonomika. 2020. № 4 (40). S. 139-150.

8. Arctic entrepreneurship development factors /Pilyasov A.N. // Geography, Environment, Sustainability. 2020. T. 13. № 1. S. 46-56. 
Рябкова О. В. Салехардская научно-исследовательская ветеринарная оленеводческая станция в 1940-1945 гг..

Исследование охватывает период с 1940 по 1945 гг. включительно и посвящено истории функционирования Салехардской научной-исследовательской ветеринарной станции по изучению болезней северных оленей Народного комиссариата земледелия СССР - первого научного учреждения Ямало-Ненецкого округа. В качестве исторических источников использованы документы, сохранившиеся в государственном архиве Ямало-Ненецкого автономного округа. В статье рассматриваются вопросы организации научной деятельности учреждения, направления работы научных сотрудников и их квалификация, определено из каких источников формировался бюджет станции. Основной задачей учреждения являлось научное сопровождение развития оленеводства в регионе. Сотрудники станции ежегодно проводили исследования в области прикладной экспериментальной ветеринарии в области оленеводства, разрабатывали методические рекомендации проведения противоэпизоотических мероприятий в колхозных, совхозных и личных оленьих стадах.

Ключевые слова: Великая Отечественная война, Ямал, ЯмалоНенеикий автономный округ, наука, олени, ветеринария, Салехардская научноисследовательская станиия

\begin{abstract}
Ryabkova O. V. Salekhard Scientific Research Veterinary Reindeer Breeding Station in 1940-1945.

The study covers the period from 1940 to 1945 inclusive and focuses on the history of the Salekhard scientific research veterinary station of the reindeer disease study of the the People's Commissariat for Agriculture of the USSR - the first scientific institution of the Yamalo-Nenets District. The documents that remained in the state archive of the Yamalo-Nenets District were used as historical sources. The article discusses the organization of the institution's scientific activity, the areas of work of researchers and their qualifications, as well as determines the budgeting sources of the station. The main objective of the institution was to provide scientific support for the development of reindeer husbandry in the region. Every year, the station staff conducted research in the field of applied experimental veterinary medicine in the field of reindeer husbandry, developed methodological recommendations for conducting animal disease control measures in collective, state-farm and personal reindeer herds.
\end{abstract}

Key words: World War II, Yamal, Yamalo-Nenets Autonomous District, science, deer, veterinary medicine, Salekhard Research Station

Для цитирования: Рябкова О. В. Салехардская научно-исследовательская ветеринарная оленеводческая станция в 1940-1945 гг. // Ойкумена. Регионоведческие исследования. 2021. № 4. C. 69-77. DOI: 10.24866/1998-6785/2021-4/69-77

For citation: Ryabkova O. V. Salekhard Scientific Research Veterinary Reindeer Breeding Station in 1940-1945 // Ojkumena. Regional researches. 2021. № 4. P. 69-77. DOI: $10.24866 / 1998-6785 / 2021-4 / 69-77$ 